Andrew R. CORIN*

Defense Language Institute Monterey
Оригинални научни рад

Примљен: 11. 11. 2016. Прихваћен: 10. 02. 2017.

\title{
„НАСТАЈАҢЕ” КАО КОМПОНЕНТА ЗНАЧЕЊА У СРПСКОМ ЈЕЗИКУ
}

\begin{abstract}
У радовима издатим 1936. и 1958. године, Р. Јакобсон је покренуо, односно унапредио и најпотпуније формулисао, концепцију компонентне анализе словенских падежних система. Иако је та идеја једно време уживала популарност, данас је скоро заборављена, делимично због преовлађивања нових приступа лингвистичкој анализи, али делимично и због тога што је Јакобсонов систем био у супротности са појединим језичким чињеницама. Овај рад прво даје кратак осврт на ову концепцију и затим пружа илустрацију зашто би она могла и данас бити привлачна ако се полази од претпоставки и методологије различитих од Јакобсонових.
\end{abstract}

Кључне речи: компонентна анализа, падежни системи, Роман Јакобсон

1. У раду за зборник у част професора Д. С. Ворта 2000. године (в. Корин 2000, који обједињује теме обрађиване у низу ранијих радова, делимично за НССУВД), осврнуо сам се на концепцију компонентне анализе словенских, у првом реду руских, падежних значења коју је формулисао Роман Јакобсон у радовима из 1936. и 1958. године (в. Јакобсон 1936/1971 и 1958/1971). Према овом приступу, значење појединих падежа у различитим конкретним контекстима увек изражава њихово опште значење (Hauptbedeutung), које се дефинише као збир њихових вредности (плус или минус) у оквиру система који се састоји од три привативне опозиције: периферно (peripheral) или непериферно, квантифицирајуће (quantifying) или неквантифицирајуће, и приписуjуће (ascriptive) или неприписуjуће. ${ }^{1}$ Опште значење словенског (руског) датива, на пример, одређује се према Јакобсону као: периферно, неквантифицирајуће и приписујуће. Значење инструментала је периферно, неквантифицирајуће али неприписуjуће (non-ascriptive), итд. На овај начин, Јакобсонов систем је мо-

\footnotetext{
*andrew.corin@dliflc.edu

${ }^{1}$ За варијантну српску терминологију, као и за додатну литературу и историјат проблематике, в., нпр., Симић 1993, а такође Ивић ²1995: 195-212.
} 
гао да опише значење падежа на компактан начин који је у складу са великим бројем чињеница, у првом реду падежних синкретизама, али и шире.

Међутим, његов систем је исто тако био у супротности с другим чињеницама, или их је барем остављао без објашњења (в. нпр. Ивић ${ }^{2} 1995$ : $195-$ 200). Један врло јасан пример представља опозиција акузатива као падежа „кретања” према локативу и инструменталу као падежима „мировања”. Ту опозицију није могуће изразити у оквирима Јакобсоновог система, барем као опозицију маркирану према немаркираној вредности једне семантичке категорије, као што бисмо очекивали.

Споменути рад из 2000. године представљао је покушај да се идеја о компонентној анализи као оквиру за разумевање системности падежних значења обнови, не у формулацији коју је предложио Јакобсон, нити на основу истих претпоставки или исте методологије, али ипак у намери да се спасе од заборава основна идеја која је и даље барем интуитивно привлачна.

Циљ је овог реферата да пружи једну илустрацију зашто би та концепција могла бити и даље привлачна, али уједно зашто ју је тешко формулисати ограничавајући се на методологију којом се служио Јакобсон. Ово ће се постићи изношењем низа чињеница које указују на једну категорију значења која игра значајну улогу у систему падежних значења српског језика, али исто тако прожима и друге језичке системе. Ове чињенице сугеришу да није корисно говорити о систему падежних значења као о одвојеном самосталном систему. Уместо тога, боље је говорити о систему семантичких категорија српског језика изражених морфосинтаксичким (а делимично и лексичким) средствима, између осталог и средствима падежног система. Ради се управо о категорији која укључује у себи као поткатегорију опозицију „кретања” према „мировању”, али је њена сфера много шира. Можемо назвати ову категорију „настајање” (или, алтернативно „инцептивност,” „ингресивност” или „инхоативност”). То што настаје може бити ентитет, својство, однос, процес или радња. Ова категорија може представљати основну или додатну компоненту значења, и реализује се на различите начине У разним морфосинтаксичким и лексичким контекстима и код глаголских и код именских речи.

2. Морфосинтаксичке реализације које ова категорија обухвата су следеће.

А. Код предикативних речи ту спада неколико скупина глагола са лексичким или граматикализованим ингресивним одн. инцептивним значењем.

Прву скупину сачињавају глаголи од корена -чн- (односно -че-/-чињ-), у првом реду почети, зачети, начети, са лексичким ингресивним значењем (в. Корин 1996). Ови глаголи изражавају настајање радње, процеса или ентитета. Та радња, процес, или ентитет настаје, зависно од префикса, или под деловањем неког агенса (нпр. радници су (за)почели радове/да раде), или без деловања неког агенса (радови су почели...). Може присуствовати и додатно значење настајања неког процеса развитка или живота (зачети) или настајања процеса конзумације (у дословном или пренесеном смислу) или обрађивања (начети). 
Другу скупину сачињавају глаголи који се творе ингресивним префиксима за- и уз-, типа загристи, узјахати и слично (в. Корин 1993, 1995). Ови глаголи такође означавају почетак, односно настајање неке радње или неког процеса, увек под деловањем спољног агенса односно носиоца. Они су делимично или потпуно синонимни са глаголима прве групе.

Трећу скупину сачињавају глаголи постајања и настајања од корена -ста- (односно -стан-/-стај-), у првом реду постати и настати (в. Корин 1994). Ови глаголи у својој најтипичнијој употреби у данашњем књижевном језику означавају настајање својства, ентитета или стања. Глагол посmaти најчешће означава настајање својства или стања код неког носиоца, док глагол настати означава настајање својства, ентитета или стања без обавезног позивања или упућивања на неког спољног носиоца тог својства или стања.

Четврту групу сачињавају глаголи са ингресивним значењем или импликацијом, типа прогласити, учинити, итд., који допуштају или захтевају другу допуну у инструменталу (прогласили/учинили су га председником).

Пету групу сачињавају глаголи кретања који значе или имплицирају настајање неког стварног или метафоричног просторног односа и захтевају допуну предлошком фразом са на/y + акузатив типа $y \hbar u$, попети се, упустити се.

Шесту групу чине глаголи кретања који значе или имплицирају настајање неког стварног или метафоричног просторног односа и захтевају допуну у дативу, типа прићи, приближити се.

Седму групу представљају глаголи дати, продати, пружити и други који значе иницирање односа поседовања или другог односа од стране неког агенса: дали, продали, пружили су му књигу.

Осму групу би могли сачињавати идиоматични глаголски изрази типа: латити се (посла) и сл.

Б. Код именских речи ту спадају следећих пет појава.

Прва, друга и трећа су разликовање падежа кретања и мировања, то јест, опозиција акузатива и датива, с једне стране, као падежа који означавају настајање неког стварног или метафоричног просторног односа између неког носиоца и дотичне локације, према падежима који означавају једноставно постојање тог просторног односа, с друге стране:

- $\quad$ акузатив (ушао сам у продавнииу): локатив (био сам у продавници)

- $\quad$ акузатив (сео је за сто, посадили су га за сто) : инструментал (седео је за столом)

- $\quad$ датив (пошао је својој сестри) : предлошка конструкција са генитивом (био је код своје сестре)

Редундантност информација које ове опозиције преносе дозвољава у многим случајевима могућност падежне неутрализације (која се разликује од падежног синкретизма као појаве са првенствено фонетском или аналошком подлогом). Прве две опозиције (,акузатив : локатив” и „акузатив : инструментал”) неутралишу се у корист акузатива у појединим дијалекатским зо- 
нама (углавном косовско-ресавским и зетско-јужносанџачким) ${ }^{2}$, док се трећа опозиција (,датив : генитив”) неутралише у корист датива у свакодневној разговорној употреби у примерима типа седео сам кући иеео дан поред седео сам код куће цеео дан, а у корист генитивске конструкције када се локација изражава именичком фразом, у примерима типа пошао сам код моје сестре поред све мање употребљаване варијанте помао сам мојој сестри.

Четврта појава код именских речи је опозиција датива као падежа иницирања посесивног или сличног односа између референта првог и другог објекта глагола (продали су кућу дошљаку из Канаде) према генитиву као падежу једноставне констатације посесивног односа (то је кућа дошљака из Канаде). У случају другог објекта глагола дати, продати, и сл., опозиција датив : генитив није редундантна, јер продали су кућу дошљаку из Канаде $\neq$ продали су кућу дошљака из Канаде, па је разумљиво да неутрализација није могућа барем у књижевном језику (имајући у виду да свођење генитивских и дативских синтагми на предлошку фразу типа на + објекатски облик именице јесте јарка особина појединих периферних дијалеката). Међутим, у изражавању једноставног односа поседовања, падежно обележавање опозиције датив : генитив је редундантно, па је разумљиво да лакше може доћи до неутрализације у контекстима у којима се користи један од тих падежа за изражавање тог односа, што се и усталило у језику од давнине. Када се поседник изражава личном заменицом, употребљава се посесивни датив (кућа му је на крају улище), а када се поседник изражава именичком фразом, користи се посесивни генитив (кућа мог стрица...), барем у књижевном језику. ${ }^{3}$ Иако се опозиција „датив : генитив” за изражавање посесивног односа ређе доводила у везу са опозицијом падежа кретања и мировања, о неутрализацији семантичке опозиције ових падежа не само у српском језику, него у ширем кругу индоевропских језика, постоји извесна литература, укључујући осврте на ову идеју у новијој литератури. ${ }^{4}$ А оваква неутрализација није непозната У типолошки сличним неиндоевропским језицима. У библијском хебрејском, предлог л' (приближан превод „к”) у свом најужем значењу изражава „дативске” појмове индиректног објекта глагола давања, као и циља којем се неко/нешто приближава. Међутим, он се среће и у контекстима у којима српски језик захтева посесивни или аблативни генитив, нпр. у насловима појединих псалама (почетак 29. псалма, мизмор л’ давид דודל רומזמ, у Даничићевом преводу Песма Давидова, који би, строго гледано, могао и да се преводи Песма Давиду, и сл.).

Пету појаву би могао представљати предикативни инструментал, барем у многим његовим типичним употребама, у алтернацији са номинативом или предлошком конструкцијом са акузативом (в. Корин 1995, 1999). Редундант-

\footnotetext{
${ }^{2}$ Треба имати у виду да је свест о семантичком разликовању „заузимања положаја” од „бивања у положају” ионако лабавија код категорије неконтактне локације (у терминологији М. Ивић „посредност у исказивању места радњи”, в. Ивић 1954: 207).

${ }^{3}$ У дискусији, Радоје Симић је упозорио на чињеницу да у појединим косовско-ресавским дијалектима долази и до обрнутог резултата падежне неутрализације (типа кућа мом стрииу).

4 За старију литературу в. Корин 1997 и Корин 2000. У новије време, в., нпр. Станишић 1989, или дистертацију Маља-Имами 2012: 41.
} 
ност информација које предикативни инструментал преноси дозвољава да се у непрелазним конструкцијама типа Постао је чланом... опозиција „номинатив : инструментал” неутралише у корист номинатива (постао је члан), тако да се предикативни инструментал у оваквим примерима сматра већ архаизмом у савременом језику. Код прелазних конструкција са глаголима типа прогласити, неутрализација није могућа у савременом језику, иако се предикативни инструментал све чешће замењује конструкцијом за + акузатив.

3. Заједнички семантички елемент у свим горе наведеним појавама, како лексичким, тако и морфосинтаксичким, а код последњих из области флексије и творбе речи, јесте значење настајања, односно инцептивности или ингресивности. То што се иницира, односно што настаје, може бити:

- радња или процес: радници су (за)почели радове, радови су почели; засвирао је, узјахао је коња; латио се посла, упустио се у посао;

- својство, ентитет или стање: постао је члан(ом) / мудрији(м), настао је град, настала је гужва; прогласили су га председником, учинили су га бољим;

- стварни или метафорични просторни однос: ушли су у кућy, ставили су га на сто, посадили су га за сто, пришли су кући;

- $\quad$ однос поседовања или њему слично значење везе или тицања: продали су му кућу, пружили су му подршку.

Радње, дакле, могу да се једноставно одвијају или да почињу да се одвијају. Ентитети или својства могу да једноставно постоје или да настају, да почињу да постоје. Просторни и други односи, на пример поседовање, исто тако могу или да једноставно постоје или да настају, да почињу да постоје.

4. Наведене чињенице су можда занимљиве саме по себи као дескриптивни факт, али да ли постижемо нешто више уочавањем тих чињеница? Ако ништа друго, индуктивна констатација о „настајању” као препознатљивој дискретној компоненти значења придаје јој педагошки значај у настави српског као страног језика, јер дугогодишња наставна пракса показује да свест о оваквој семантичкој компоненти може олакшати задатак поготово онима који желе да постигну више нивое говорних компетенција у српском и њему типолошки сродним језицима. Али зато тај педагошки значај као да упућује на закључак да би таква претпостављена компонента значења била значајна и за лингвистички опис језика.

Даље, исте чињенице илуструју колико падежи српског језика, иако показују системност у употреби, ипак не представљају, барем у овим контекстима, одвојен и самосталан систем, већ делују заједно са осталим морфосинтаксичким и чак лексичким средствима језика у изражавању поједине семантичке категорије.

Гледано с обрнуте стране, сама чињеница да можемо препознати координирано функционисање истог језгра значења у разним системима српског језика - код глагола у више лексичких скупина и у творби речи, а код именских речи у флексији, и то различито код именица, придева и личних 
заменица - служи као подршка закључку да се ради заиста о једној дискретној компоненти значења односно, са гледишта морфосинтаксе, о дискретној семантичкој опозицији која се изражава различито у разним лексичким и морфосинтаксичким контекстима. Код глагола почети, то је у ствари цело, или барем главно, лексичко значење. Код других глагола, „настајање” је семантички додатак, изражен префиксом, суфиксом или превојем са променом глаголске врсте, основном лексичком значењу глагола.

За глаголе типа загристи или узјахати, могао би се ставити противаргумент да ти глаголи не значе само „почети гристи” и „почети јахати”, него укључују и пропратне семантичке компоненте. Колико су ови префикси ипак близу потпуне граматикализације у значењу „настајања дотичне радње” показује занимљив случај хрватске редакције црквенословенског језика, где се управо то и десило са префиксом в 'з- (који по пореклу одговара савременом српском префиксу уз-), тако да се инцептивни глагол с овим префиксом могао јављати (и заиста се често јављао) у слободној алтернацији са конструкцијом од инцептивног глагола в 'чети (савремено српско почети) + инфинитив (Корин 1993:169). О томе сведоче многи примери типа aћe в'схоћете и послушати в'чнете ме, благаја землскаја снпсте (Исаија 1:19) у једним рукописима поред аће в'схоћете и в'спослушаете ме у другима (у Даничићевом преводу ако хоћете слушати, добра земаљска јешћете). ${ }^{5}$

Код трећих глагола „настајање” се може сматрати као једна од више нераздвојивих компонената основног лексичког значења глагола, на пример код глагола прогласити, где се свест о „настајању” као дискретној компоненти значења сигналише обавезном употребом инструментала или з $a+$ акузатив за другу допуну глагола. Глаголи зачети и начети сужавају значење глагола почети прецизирајући да се ради о настајању живота или процеса, односно о настајању конзумације или обрађивања.

Има још један потенцијални противаргумент (или барем начелно питање) који би се могао поставити у вези са идејом која се овде излаже. Чак и признајући да је могуће издвојити семантичку категорију „настајања” на овај начин, зар нас не интересује више, барем што се тиче падежног система, шта је то што уједиғује сва значења сваког појединог падежа? Рецимо, за генитив шта је то што уједињује његово посесивно значење, објекатско, партитивно, итд., и шта је то што раздваја сва та значења генитива од свих значења неког другог падежа, рецимо датива? То је и био Јакобсонов циљ. Једноставна констатација о постојању неке конкретне компоненте значења као што је „настајање" која се не да разумети у оквирима Јакобсоновог система не доприноси изналажењу бољег одговора на то оригинално питање, барем на основу истих теоријских постулата, већ једино указује на ману у систематизацији коју је Јакобсон предложио, и доводи у питање основни постулат о падежним системима као кохерентним затвореним системима у којима сваки падеж изражава неко јединствено и обавезно опште значење (Hauptbedeutung). Идеја

\footnotetext{
${ }^{5}$ Даничићев превод с употребом футура веран је хебрејском, грчком и латинском предлошку, док хрватскоцркенословенски текст одступа од њих, по свој прилици услед недостатка морфолошког „футура” као глаголског времена.
} 
изложена у овом реферату као да упућује радије на неку врсту „генеративне семантике" која би обухватала, између осталог, употребу свих падежа осим вокатива за изражавање категорије „настајања”, али у оквирима ширег система изражавања појединих семантичких категорија.

У наставку можемо једино у најкраћем спекулативном облику да укажемо на један потенцијални правац размишљања у којем би се укрштали семантички, синтаксички и логички приступи језичком опису, и заиста подсећа донекле на неку врсту оживљене генеративне семантике. Ово излагање не претендује на строгост у формулацији, већ му је циљ да укаже на један могући правац за даља истраживања.

С једне стране, већ смо констатовали да се „настајање” као компонента значења комбинује са другим компонентама значења на начин који поједностављује дефинисање појединих лексичких јединица. Као једноставан пример комбиновања више дискретних семантичких компонената можемо навести глагол постати, који у најтипичнијој савременој употреби служи као инцептивни парњак за глагол бити у копулативној употреби, док глагол настати служи као инцептивни парњак за глагол постојати или бити у егзистенцијалној употреби. Другим речима, лексичко значење ових глагола може да се карактерише као „настајање + копулативни однос” или „настајање + егзистенција".

С друге стране, неки од горе наведених примера упућују на идеју да понекад то што осећамо као опипљиву компоненту лексичког значења може бити само привидно, а у ствари представља импликацију синтаксичког контекста у којем се поједина реч јавља, односно логичке структуре реченице у којој се та реч јавља. Ако узмемо реченицу они га чине председником, можемо је парафразирати као они чине да он буде председник. Ако је тако, можемо описати њено значење у виду бинарно рачвасте структуре Фигуре 1:

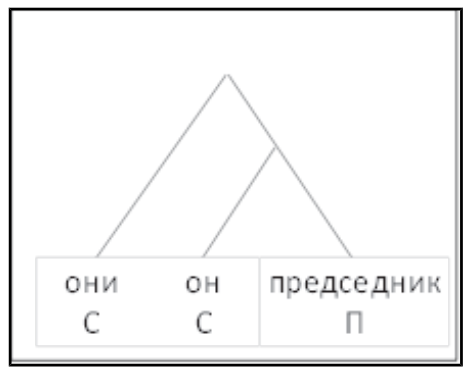

ФИГУРА 1

У овој фигури сваки леви крак представља односно дефинише се као „субјекат” (агенс или носилац) а сваки десни крак представља „предикат”. У овој фигури, дакле, имамо нижу реченицу, односно нижи предикативни спој, у којем је субјекат он а именички предикат је председник, док цео тај нижи предикативни спој „субјекат он + предикат председник” служи као предикат у склопу горњег предикативног споја (односно реченице) чији је субјекат они. 
Тај горњи субјекат (тј., субјекат „површинске” реченице) служи семантички као агенс који реализује/остварује нижи предикативни спој, а глагол чине служи првенствено као лексички носилац обавезних морфосинтаксичких категорија предиката - време, модус, вид, број и лице. Ако је тако, сам глагол чинити не додаје у овом примеру неко конкретно лексичко значење. Може имати неко пропратно значење у датом контексту, али то није обавезно.

Можемо ићи још један корак даље у оваквом размишљању. Реченица они га чине председником има два могућа значења зависно од контекста. Прво, може да значи да „они” инищирају копулативни однос „он је председник”. Са имперфективним глаголом у презенту, ово контекстуално значење је мање вероватно (осим ако се ради о итеративном значењу), док са свршеним глаголом (они су га учинили председником) то је највероватније значење. Друго контекстуално значење је да „они својим присуством или напорима остварују или реализују однос „он је председник” синхроно, континуирано, без упућивања на неки почетни тренутак. У несвршеном презенту, ово је заправо највероватније контекстуално значење, оно што прво пада на памет када чујемо ову реченицу. Ово сугерише да значење „настајања” у овим примерима не само што је чиста импликација контекста у којем субјекат реченице служи као агенс остваривања предикативног споја означеног подређеном „реченицом” (тј., нижом рачвастом структуром), него је значење „настајања” само једна од могућих импликација таквог контекста, зависно од вида глагола.

Све што је наведено у овим последњим пасусима не претендује, опет, на прецизност научног модела, а оставља по страни друге очигледно повезане чињенице, као што су однос „настајања” према другим фазним значењима, и фазне импликације глаголског вида. Сврха ових размишљања је била само да употпуне илустрацију зашто идеја о компонентној анализи падежних значења остаје занимљива, и да укажу на неке од праваца у којима би будућа истраживања могла евентуално кретати, између осталог и у оквирима нових модела језичког описа. За Јакобсона ово је представљало питање семантичке структуре падежних система као таквих, али чињенице и идеје које су овде изложене сугеришу да би адекватнији модел полазио од ширих погледа у којима би структура падежног система била испреплетена са широм семантичком и морфосинтаксичком структуром језика, и у којима се падежна значења не могу раздвојити од значења лексичких и других морфосинтаксичких система језика. 


\section{ЛИТЕРАТУРА}

Ивић 21995: Милка Ивић, Лингвистички огледи, Београд: Словограф.

Јакобсон 1936/1971: R. Jakobson, „Beitrag zur allgemeinen Kasuslehre: Gesamtbedeutungen der russischen Kasus", Selected Writings II, The Hague: Walter de Gruyter, 23-71.

Јакобсон 1958/1971: R. Jakobson, „Морфологические наблюдения над славянским склонением (состав русских падежных форм)", Selected Writings II, The Hague: Walter de Gruyter, 154-183.

Корин 1993 (1994): Andrew R. Corin, „Variation and Norm in Croatian Church Slavonic", Slovo, 41-43, 155-196.

Корин 1994: Andrew R. Corin, „Inceptive and Conceptive Verbs in Slavic”, Die Welt der Slaven 39, 113-143.

Корин 1995: Andrew R. Corin, „Предикативни инструментал у савременом српскохрватском језику", НССУВД, 24/1, 73-80.

Корин 1996: Andrew R. Corin, „Постати и настати и њихови еквиваленти у словенским језицима", Српски језик 1-2 (Зборник у част проф. Живојина Станојчића), 39-48.

Корин 1997: Andrew Corin, „О синтакси егзистенцијалног habere (има) у српском језику", НССУВД, 26/2, 45-60.

Корин 1999: Andrew R. Corin, „Хијерархије у изражавању номиналног предиката у савременом српском језику", НССУВД, 28/2, 247-256.

Корин 2000: Andrew R. Corin, „Componential Analysis of Slavic Case: A New Look at an Old Idea", In the Realm of Slavic Philology: To Honor the Teaching and Scholarship of Dean S. Worth from his UCLA Students, ред. J. Dinglеу и L. Ferder, Bloomington: Slavica, 35-50.

Маља-Имами 2012: Nailje R. Malja-Imami, Konvergencija i divergencija padežnih sistema u balkanskom jezičkom arealu. Doktorska disertacija, Beograd. (https://fedorabg.bg.ac.rs/fedora/get/o:7073/bdef:Content/get)

Симић 1974: Радоје Симић, „Приступ морфематици именичких речи”, Зборник за филологију и лингвистику, 17/2, 88-109.

Станишић 1989: Vanja Stanišić, „O nekim sličnostima u padežnom sistemu između albanskog i srpskohrvatskog jezika”, Balcanica, XX, Beograd, 357-367. 


\title{
Andrew Corin \\ “BECOMING” AS A COMPONENT OF MEANING IN SERBIAN LANGUAGE
}

\begin{abstract}
Summary
Componential analysis of the Russian case system, and by extension other Slavic case systems, was developed in two stages by R. Jakobson in works published in 1936 and 1958. According to this conception, the meaning of individual cases in differing contexts always expresses their general meaning (Hauptbedeutung), defined as their values (plus or minus) within a system of three privative oppositions: peripheral vs. non-peripheral, quantifying vs. non-quantifying, and ascriptive vs. non-ascriptive. This allowed Jakobson to define the meaning of cases in a compact manner that was in accord with numerous facts, particularly of case syncretism. However, this system also failed to encompass other striking facts, including the opposition between cases of "destination" vs. those of static "location." The conception of componential analysis of case systems based on Jakobson's model gradually lost popularity, presumably due in part to such contrary facts. The objective of this paper is to illustrate why the concept of componential analysis of case systems should still be attractive, though based on assumptions and methodology different from Jakobson's.
\end{abstract}

Key words: componential analysis, case systems, Roman Jakobson, Hauptbedeutung. 